IZA DP No. 6558

The Gender Pay Gap in the Australian Private Sector: Is Selection Relevant across the Wage Distribution?

Yekaterina Chzhen

Karen Mumford

Catia Nicodemo

May 2012 


\title{
The Gender Pay Gap in the Australian Private Sector: Is Selection Relevant across the Wage Distribution?
}

\author{
Yekaterina Chzhen \\ University of Oxford \\ Karen Mumford \\ University of York \\ and IZA
}

Catia Nicodemo

Universitat Autònoma de Barcelona

and IZA

Discussion Paper No. 6558
May 2012

IZA

P.O. Box 7240

53072 Bonn

Germany

Phone: $+49-228-3894-0$

Fax: +49-228-3894-180

E-mail: iza@iza.org

Any opinions expressed here are those of the author(s) and not those of IZA. Research published in this series may include views on policy, but the institute itself takes no institutional policy positions.

The Institute for the Study of Labor (IZA) in Bonn is a local and virtual international research center and a place of communication between science, politics and business. IZA is an independent nonprofit organization supported by Deutsche Post Foundation. The center is associated with the University of Bonn and offers a stimulating research environment through its international network, workshops and conferences, data service, project support, research visits and doctoral program. IZA engages in (i) original and internationally competitive research in all fields of labor economics, (ii) development of policy concepts, and (iii) dissemination of research results and concepts to the interested public.

IZA Discussion Papers often represent preliminary work and are circulated to encourage discussion. Citation of such a paper should account for its provisional character. A revised version may be available directly from the author. 


\section{ABSTRACT}

\section{The Gender Pay Gap in the Australian Private Sector: Is Selection Relevant across the Wage Distribution?*}

We use quantile regression and counterfactual decomposition methods to explore gender gaps across the earning distribution for full-time employees in the Australian private sector. Significant evidence of a self selection effect for women into full-time employment (or of components of self selection related to observable or unobservable characteristics) is, interestingly, not found to be relevant in the Australian context. Substantial gender earnings gaps (and glass ceilings) are established, with these earnings gaps found to be predominantly related to women receiving lower returns to their observable characteristics than men.

JEL Classification: J3, J7

Keywords: gender, earnings, selection, quantile distribution

Corresponding author:

Karen Mumford

Department of Economics and Related Studies

University of York

Heslington

York YO10 5DD

United Kingdom

E-mail: karen.mumford@york.ac.uk

\footnotetext{
* We thank the HILDA providers - FaHCSIA owns all intellectual property rights of the data used in this work. The findings and views reported in this work, however, are those of the author and should not be attributed to either FaHCSIA or the Melbourne Institute. We are also very grateful to James Albrecht, Peter Smith, Susan Vroman and Aico van Vuuren.
} 


\section{Introduction}

Studies of the gender pay gap across the earnings distribution that allow for possible non-random selection of women into full-time employment are relatively new to the economics literature. Some recent examples include Albrecht et al., (2009) for the Netherlands; Nicodemo (2009) for Mediterranean countries; and Chzhen and Mumford (2011) for Britain. These three studies find significant and substantial positive self-selection effects for women into full-time employment and sizable adjusted gender pay gaps that are primarily related to gender differences in returns to characteristics ${ }^{1}$.

In the Australian context, Kee (2006) uses the first wave of the Household, Income and Labour Dynamics (HILDA 2001) data to consider gender pay gaps across the earnings distribution. She finds evidence of a glass ceiling for women in the private sector but she does not find significant evidence of self selection of women into full-time employment (Kee 2006, footnote 13). This result is perhaps surprising as early Australian studies of gender wage gaps at the mean of the earnings distribution established significant sample selection effects for women in the 1982 full-time labour market (Kidd and Viney, 1991); and for young people aged between 19 and 26 who were working full-time in 1985 (Miller and Rummery, 1991). Subsequent papers rarely explored selection issues, however, (for a survey see Borland 1999). More recently, Watson (2010) pools waves 1 to 8 of the HILDA data (2001 to 2008) to consider the pay gap amongst managers; a group of employees typically found amongst high earning employees. Watson (2010) uses decomposition at the mean techniques to establish a substantial unexplained gender pay gap and he finds no significant self-selection effect for women.

Miller (2005) and Baron and Cobb-Clark (2010) further explore gender pay gaps across the earnings distribution for Australia. Miller (2005) uses Census data from 2001 and finds evidence of a substantial glass ceiling for women. Baron and Cobb-Clark (2010) pool waves 1 to 6 of the HILDA data (2001 to 2006) and find evidence of glass ceilings in both public and private sectors. Neither Miller (2005) nor

\footnotetext{
${ }^{1}$ The literature on gender wage inequality at the mean is well established (see surveys by Altonji and Blank, 1999; Weichselbaumer and Winter-Ebmer, 2005).
} 
Baron and Cobb-Clark (2010) explicitly test for possible non-random self-selection of women into employment ${ }^{2}$.

In this paper, we seek to further explore the issue of self-selection of women into full-time employment in the Australian private sector. In particular, following Kee (2006) we use the quantile regression decomposition method (Machado and Mata, 2005) to study the gender wage gap in log average hourly earnings across the distribution for full-time private sector workers in Australia in 2009 including explicit allowance for possible non-random selection of women into full-time employment. We further explore the finding of Kee (2006) by applying the recently developed selection correction technique presented in Albrecht et al., (2009) which allows for decomposition of the selection term into the components associated with observed and unobserved characteristics, respectively.

Data and variable selection are discussed in the next section, estimation methods and sample selection are considered in section 2, results are presented and discussed in sections 3 and 4, and conclusions are presented in section 5.

\section{Wage Data and the Earnings Function}

The data are taken from the Household, Income and Labour Dynamics (HILDA) ${ }^{3}$ survey which is a nationally representative, annual sample of private Australian households. The HILDA survey was launched in 2001. Each year, individual adult members (those aged 15 years and over) of households are interviewed over a broad range of socioeconomic topics; with particular emphasis on income, labour market characteristics, and family formation. HILDA is a rich and relevant data set for our purposes. We make use of wave nine of the HILDA data which collects information from 2009 and was made available in 2011 (for technical details see Watson, 2009). We also include relevant lagged data from 2008.

\footnotetext{
${ }^{2}$ Although Miller (2005) does divide his sample by education in his analysis.

${ }^{3}$ FaHCSIA owns all intellectual property rights of the data used in this work. The findings and views reported in this work, however, are those of the author and should not be attributed to either FaHCSIA or the Melbourne Institute.
} 
To focus on the full-time employed (and those least likely to be in full-time education or retirement) the sample is restricted to individuals in the 25 to 55 age bracket. Non-working and part-time employed men are excluded from the sample as are the self-employed; public sector employees; the minority of workers with no expected weekly working hours; those reporting working more than 75 hours per week; and those with missing data on any of the labour market or personal characteristics included in the analysis below. The final sample contains observations for 2,896 individuals, of whom 2,312 are waged or salaried workers (1,414 male and 898 female) in the private sector with a further 584 non-working women. Variable definitions and summary statistics for the sub-samples of interest are presented in Table 1 (further summary statistics for the samples of interest are provided in Table A1 of the Appendix).

\section{II.i The distribution of wages}

The wage measure used in the analysis is the natural logarithm of average gross hourly earnings in main job. It is derived from gross current weekly pay and total weekly hours worked. Men's average hourly wages are substantially higher than women's in Australia (see Table 1): the mean gender earnings gap amongst full-time workers is 17 log wage points. The distribution of earnings is considered in Figure 1 which plots the estimated kernel densities of wages for men and women working fulltime. The distribution of male wages is essentially symmetric, while the corresponding female distribution is unsurprisingly somewhat skewed to the left.

The raw (unadjusted) gap in log hourly wages between male and female fulltime employees at each quantile of the distribution ${ }^{4}$ is plotted in Figure 2; this is the difference in the distributions of earnings shown in Figure 1. The gender pay gap can be seen to be steadily increasing until around the $70^{\text {th }}$ percentile, thereafter it plateaus at some $20 \log$ wage points.

\section{II.ii The determinants of wages}

Most authors have adopted the human capital model as the theoretical basis for the earnings function (Becker, 1962 and 1964; Mincer, 1958). This approach is also used

\footnotetext{
${ }^{4}$ The 95\% confidence interval is estimated via bootstrapping with 100 repetitions (see Melly, 2006).
} 
here. At the individual employee level, it is assumed that wages increase with measures of accumulated skills such as education and work experience. Education is measured by the highest educational qualification level achieved (see Table 1). Work experience is the accumulated years of actual labour market work experience. The earnings function is augmented by the inclusion of further explanatory variables: marital status; migrant status (native Australian, migrant from an English speaking country, or migrant from a non-English speaking country); occupation; having managerial supervisory duties; firm size (as measured by the size of the workforce); and region. (Variable definitions and summary statistics are provided in Table 1.)

Considering these characteristics in more detail, 28\% of full time working women in the private sector in Australia have a degree, 23\% of full time working men and $23 \%$ of non working women do, whilst only $19 \%$ of part-time working women have degrees. The men have considerably more years of accumulated work experience, especially compared to non working women (20.2 years relative to 12.7 years). Non-working women are slightly less likely to be married than are full-time working men. Men are disproportionately represented in the managerial occupation as well as in technicians and trades, and amongst machinery operators. In contrast, women are over-represented in clerical and administrative occupations and in personal services, especially amongst women working part-time.

Allowance for possible non-random selection of women into full-time employment is included in the estimation of the earnings functions below (Heckman 1978; Buchinsky 1998). To identify the selection effect, additional information on the age of the youngest child present in the household, (annual) lagged non-own labour household income ${ }^{5}$, own age; and the worker's (annual) lagged response to the attitudinal statement "preschool children suffer if the mother works full-time” are included in the analysis. ${ }^{6}$ Non-working women are considerably more likely to have

\footnotetext{
${ }^{5}$ Non own-labour household income is financial year annual gross household income in, the single period lag of, the reference period (12 months before the interview) minus the individual's own gross income from labour in that same period.

${ }^{6}$ Fortin (2005) and Albrecht et al., (2009) both stress the importance of including attitudinal (or belief) measures in the analysis of women's employment decisions. This may be particularly important for beliefs that vary across individuals and cultural groups (such as the relationship between working hours and the perceived ability to be a successful mother).
} 
pre-school aged children. They are also considerably more likely to believe that preschool children suffer if their mother is working full-time (Table 1).

\section{Estimation and selection}

The quantile regression model of Koenker and Bassett (1978) is employed to estimate earnings functions for (the two groups, males $m$ and females $f$, who make up) the population $j$ at quantile $\theta$ :

Quant $_{\theta}\left(W_{j} \mid X_{j}=x_{j}\right)=x_{j} \beta^{j}(\theta) \quad \theta \in[0,1]$

where $W$ is the endogenous variable (the natural log of average hourly earnings); $X$ is a stochastic vector of regressors measuring a range of characteristics; and $x$ is the realisation of this stochastic vector.

The need to allow for sample selection (such as the non-random probability of women working full-time) when estimating an earnings function is well documented by Heckman (1979). Buchinsky (1998) proposes a semi-parametric estimator for selection correction in the quantile regression model and provides examples. Albrecht et al., (2009) employ the Buchinsky method and extend the Machado-Mata (2005) decomposition technique to account for selection in the quantile regression framework ${ }^{7}$, by estimating:

$\operatorname{Quant}_{\theta}\left(W_{f f} \mid Z_{f f=} Z_{f f}\right)=x_{f f} \beta^{f}(\theta)+h_{\theta}\left(z_{f f} \gamma\right) \quad \theta \in[0,1]$

where $f$ denotes all women; $f f$ denotes those women working full-time; $Z_{f f}$ is the set of observable characteristics that influence the probability that a woman works full-time ${ }^{8}$; $\beta^{f}(\theta)$ is the true value of the coefficient corrected for selection at the $\theta^{\text {th }}$ quantile; and the term $h_{\theta}\left(z_{f f} \gamma\right)$ corrects for selection at the $\theta^{\text {th }}$ quantile. Buchinsky (1998) suggests a series estimator (a power series approximation) for this flexible selection term.

\footnotetext{
${ }^{7}$ We are very grateful to James Albrecht, Susan Vroman and Aico van Vuuren for advice and the generous provision of code used in this analysis.

${ }^{8}$ For identification, $Z_{f f}$ also includes at least one variable not included in $X_{f}$. The additional variables included are discussed more fulsomely in the data section, they are the age of children present in the household; lagged non-own labour household income; the lagged worker's response to the attitudinal statement "the family suffers if the mother works full-time"; and own age.
} 


$$
\hat{h}_{\theta}\left(z_{f f} \gamma\right)=\partial_{0}(\theta)+\partial_{1}(\theta) \tau\left(z_{f f} \gamma\right)+\partial_{2}(\theta) \tau\left(z_{f f} \gamma\right)^{2}+\cdots
$$

where $\tau$ is the inverse Mills ratio; notably the $\delta$ 's vary with $\theta$; and $\gamma$ is estimated using a single-index method (Ichimura, 1993). The intercept in the wage equation $\left(\beta_{0}^{f}(\theta)\right)$ and $\left.\delta_{0}(\theta)\right)$ are not separately identified in the quantile regression model. Following Buchinsky (1998), the intercept in the wage equation is estimated via identification at unity (Andrews and Schafgan, 1998). ${ }^{9}$

Table 2 provides results from standard probit and single index (Ichimura, 1993) estimation of the determinants of participating in full-time work by women (in columns 1 and 2, respectively) ${ }^{10}$. Unsurprisingly, women are found to be significantly more likely to be working full-time if they have more years of work experience. There is some evidence that women with higher education levels are more likely to be participating, although these results are not strongly significant. In contrast, being married, having high household income (net of own earnings) and the presence of young dependent children are all strongly negatively related to the probability of women participating in full-time employment. Women are also significantly more likely to work full-time if they disagree with the attitudinal statement "the preschool child suffers if the mother works full-time”.

Figure 3 plots the difference between the selection-corrected distribution (simulated) and the actual distribution of full-time women's wages in the Australian private sector or, in other words, the selection effect across the distribution. In accordance with Kee (2006) using earlier data, the selection effect can be seen to be insignificantly different to zero (with some small exceptions around the median of the distribution). In other words, the women observed to be working full-time in the Australian private sector do not typically have higher earnings potential in this work than do Australian women in general; this is especially true for women in the lower

\footnotetext{
${ }^{9}$ By choosing a subsample of women whose observable characteristics are such that their probability of working is arbitrarily close to one, this subsample can be used to estimate the intercept in the wage equation $\left(\beta_{0}^{f}(\theta)\right)$ without adjusting for sample selection (Andrews and Schafgan, 1998).

${ }^{10}$ The constant and the coefficient on the first reported continuous variable (years of work experience) reported in Table 2 are not identified in the single index model, they are normalised here by setting them equal to the corresponding values in the probit model, thereby making the results of the two models comparable.
} 
(and upper) four deciles of the earnings distribution. ${ }^{11}$ The selection effect can be decomposed into the portion due to observable characteristics and the portion due to unobservable characteristics; this allows us to address the possibility that the two portions are offsetting each other.

Modifying the algorithm and sampling from the empirical distribution of fulltime women only (Albrecht et al., 2009) produces a distribution of wages that would be observed if women who do not work full-time had the same distribution of observed characteristics as those who actually do work full-time. The difference between this distribution and the distribution obtained by sampling from data on all women gives the portion of the selection effect due to observable characteristics (see Figure 3a). The portion due to unobservable characteristics (Figure $3 \mathrm{~b}$ ) is the difference between the distribution of wages obtained by sampling from data on fulltime women and the actual distribution of full-time women's wages.

The portion of the selection effect related to observable characteristics can be seen to be statistically insignificantly different to zero for most of the earnings distribution with limited evidence of a minor effect between the $20^{\text {th }}$ and $40^{\text {th }}$ percentiles and around the $80^{\text {th }}$ percentile (Figure 3a). The portion of the selection effect related to unobservable characteristics is similar in size and shape across the distribution, but with no significant findings at any quantile, with the exception of a small dip at the $80^{\text {th }}$ percentile (Figure $3 \mathrm{~b}$ ). These results reveal that the typically insignificant selection effect of women into full-time employment shown in Figure 3 is indeed related to insignificant differences in both observable and unobservable characteristics associated with higher earnings potential between those women who work full-time in the private sector and all women. This finding starkly contrasts with findings from similar studies for other countries (Albrecht et al., (2009) for the Netherlands; Nicodemo (2009) for Mediterranean countries; and Chzhen and Mumford (2011) for Britain). Whilst there are many possible explanations, one may be the historical under-provision of paid maternity leave in the Australian private

\footnotetext{
${ }^{11}$ The inclusion of the estimated inverse Mills ratio in the earnings regression at the mean is also found to be statistically insignificantly different from zero at standard confidence levels.
} 
sector. ${ }^{12}$ Recent legislation (effective from January 1, 2011) now allows for a Federally funded minimum period of 18 weeks of paid parental leave for the primary carer (expected to be typically the mother) from the date of birth (or adoption). Evidence from the UK suggests that the use of this type of paid leave by mothers is associated with mothers maintaining their career profile and higher earnings; and that this is especially so for more highly educated women (Gregg et al., 2007). The increased availability of this benefit in Australia is likely to lead to a sorting of women into those who have characteristics associated with higher pay and who also qualify for paid maternity leave from those who don't, lowering the movements of the former in and out of the labour market with the birth of their children (Gordon, 2012). Testing this hypothesis will be an interesting area for future research when the data become available for Australia.

Including a (positive) selection correction term, in the current example, would be expected to lead to incorrect (over) estimates of the true extent of the gender earnings gaps in Australia. To reiterate, the results presented in Figures 3, 3a and 3b suggest that no selection correction is necessary in the following estimation of the earnings functions for these full-time working women.

\section{Earnings function results}

Results from the quantile regression estimates of log average hourly earnings (equation 1) for men and for women working full-time in Australia are presented in panels 1 and 2 of Table 3, respectively. (Additional estimation results are available from the authors upon request.)

The human capital measures (education, experience and experience squared) are typically found to be significant across the wage distribution and to have the expected relationship with earnings for men (Table 3, panel 1). Furthermore, the substantial gains associated with higher education qualifications are increasing with higher earnings levels. Having a skilled occupation (especially managerial,

\footnotetext{
${ }^{12}$ In 2010, 55\% of large private sector organisations (with 100 or more employees) in Australia reported that paid maternity leave was available (on average, an entitlement of some 9 weeks), however, many women were not eligible to access this provision (EOWA 2011). In 2003, only 35.6\% of these large firms had paid maternity leave entitlements (EOWA 2011; page 2) .
} 
professional or technical) and carrying out supervisory duties are also associated with increasing returns for higher earning males. In contrast, working in a small workplace (less than 20 employees) is negatively associated with wages for men and this effect is relatively constant across the earnings distribution.

The results are different and less precisely estimated for women working fulltime. The returns to education are substantially lower for women and are not clearly rising across the earnings distribution ${ }^{13}$. This is also true for work experience which is not found to have a significant relationship with wages across the earnings distribution for women. In contrast, rising returns associated with being a manager are clear amongst higher earning women and these are substantially larger returns than those found for high earning male managers. Unlike full-time males, the returns associated with professional occupations are not substantially higher for those at the $80^{\text {th }}$ than those at the $20^{\text {th }}$ percentile of the female earnings distribution. Returns associated with supervisory duties for women are large and apparently rising with higher earnings.

Figure 4 plots the counterfactual log wage gap between full-time working men and full-time working women after adjusting for the observable characteristics of these employees. In other words, Figure 4 plots the difference between the distribution of men's wages and the (simulated) distribution of wages that women would receive if women had their own returns to characteristics, but the distribution of these characteristics are the same as that of the men. Compared with the raw gender earnings gap (Figure 2), the adjusted gender earnings gap is very similar, which suggests that most of the observed gender wage gap among full-time employees is due to differences in returns to labour market characteristics. This is confirmed by Figure 5 which provides the counterfactual distribution of the gap between men's wages and the wages that women would earn if women working full-time retain their own distribution of characteristics but are rewarded for them like men working fulltime. This gap is typically not statistically significantly different from zero throughout the distribution indicating that the gender gap would essentially disappear if these women's returns to their observed characteristics were equal to the men's.

\footnotetext{
${ }^{13}$ Significant returns to higher levels of education are observed at the median only.
} 


\section{Conclusion}

The mean gender wage gap between full-time workers in the Australian private sector (in 2009) is found to be substantial at 17 log wage points. Considering the wage gap at each percentile of the male and female earning distributions, however, reveals a more complex picture: the raw gender wage gap shows a tendency to increase across the earnings distribution until around the $70^{\text {th }}$ percentile, it then plateaus at some 20 log wage points.

Using quantile regression decomposition methods (Machado and Mata, 2005), and including allowance for possible non-random selection of women into full-time employment in Australia (Albrecht et al., 2009), we do not find significant evidence of sample selection. Decomposing the selection effect further reveals that the component related to the observed and the component related to the unobserved characteristics of women working full-time are both also typically insignificantly different to zero across the earnings distribution. These results imply that selection correction is not necessary when estimating the earnings of Australian women working full-time in the private sector in 2009; including such a correction may lead to an incorrect estimate of the gender wage gap.

After allowing (adjusting) for gender differences in the observable characteristics associated with higher earnings, a large full-time gender earning gaps remains. The observed gender wage gap is found to be predominantly related to women receiving lower rewards for their characteristics than men, rather than having a distribution of characteristics associated with lower earnings potential. Indeed, the results suggest the gender wage gap between men and women working full-time in the Australian private sector in 2009 would essentially disappear if these women's returns to their observed characteristics were equal to the men's. 


\section{References}

Albrecht, J. van Vuuren, A. and Vroman, S. (2009), 'Counterfactual Distributions with Sample Selection Adjustments: Econometric Theory and an Application to the Netherlands', Labour Economics 16(4), 383-396.

Altonji, J.G. and Blank, R. (1999), 'Race and Gender in the Labor Market' in Ashenfelter, O. and Card, D. (eds) Handbook of Labor Economics. Elsevier Science B.V, Amsterdam.

Andrews, D. and Schafgans, A. (1998), 'Semiparametric Estimation of the Intercept of a Sample Selection Model', Review of Economic Studies 65(3), 497-517.

Baron, J.D. and Cobb-Clark, D.A. (2010), 'Occupational Segregation and the Gender Wage-Gap in Private and Public Sector Employment: A Distributional Analysis', Economic Record 86(27), 227-246.

Becker, G.S. (1962), 'Investment in Human Capital: A Theoretical Analysis', Journal of Political Economy 70, 9-49.

Becker, G.S. (1964), Human Capital: A Theoretical and Empirical Analysis, with Special Reference to Education. The University of Chicago Press, Chicago.

Buchinsky, M. (1998), 'The Dynamics of Change in the Female Wage Distribution in the USA: A Quantile Regression Approach', Journal of Applied Econometrics 13, 1-30.

Chzhen, Y. and Mumford, K. (2011), 'Gender Gaps across the Earnings Distribution for Full-Time Employees in Britain: Allowing for Sample Selection', Labour Economics 18(6), 837-844.

EOWA Equal Opportunity for Women in the Workplace Agency. (2011), Paid Maternity Leave in 2011: The Business Case. Australian Government Publication accessed on May $7^{\text {th }} 2012$ from http://www.eowa.gov.au/Information_Centres/Resource_Centre/Statistics/Paid _Maternity_Leave_Business_Case_PML_Apr2011.pdf

Fortin, N. (2005), 'Gender Role Attitudes and the Labour Market Outcomes of Women across OECD Countries', Oxford Review of Economic Policy 21(3), 416-438.

Gordon, J. (2012), 'Wages in Managed Markets: An Explanation of the Gender Wage Gap?' Australian Economic Review 45(2), 1-16.

Gregg, P. Gutierrez-Domenech, M. and Waldfogel, J. (2007), 'The Employment of Married Mothers in Great Britain: 1974-2000', Economica 74(296), 842-864.

Heckman, J. (1979), 'Sample Selection Bias as a Specification Error', Econometrica 47, 153-161.

Ichimura, H. (1993), 'Semiparametric Least Squares (SLS) and Weighted SLS Estimation of Single Index Models', Journal of Econometrics 58, 71-120.

Kee, H.J. (2006), 'Glass Ceiling or Sticky Floor? Exploring the Australian Gender Pay Gap’, Economic Record 82(259), 408-427.

Kidd, M.P. and Viney, R. (1991), "Sex discrimination and non-random sampling in the Australian labour market.” Australian Economic Papers 30(56); 50-69.

Koenker, R. and Bassett, G. (1978), 'Regression Quantiles', Econometrica 46, 33-50.

Machado, J.A. and Mata, J. (2005), 'Counterfactual Decomposition of Changes in Wage Distributions using Quantile Regression', Journal of Applied Econometrics 20, 445-465.

Melly, B. (2006), 'Estimation of Counterfactual Distributions using Quantile Regression', Review of Labor Economics 68, 543-572. 
Miller, P. and Rummery, S. (1991), 'Male-Female Wage Differentials in Australia: A Reassessment', Australian Economic Papers 30(56), 28-49.

Miller , P.W. (2005), 'The Role of Gender among Low-Paid and High-Paid Workers', The Australian Economic Review 38(4); 405-417.

Mincer, J. (1958), 'Investment in Human Capital and Personal Income Distribution', Journal of Political Economy 66(4), 281-302.

Nicodemo, C. (2009), 'Gender Gap and Quantile Regression in European Families', IZA Discussion Paper No. 3978.

Watson, I. (2010), 'Decomposing the Gender Pay Gap in the Australian Managerial Labour Market', Australian Journal of Labour Economics 13(1), 49 - 79.

Weichselbaumer, D., and Winter-Ebmer, R. (2005), 'A Meta-Analysis of the International Gender Wage Gap’, Journal of Economic Surveys 9, 479-511. 
Table 1 Variable Definitions and Means

\begin{tabular}{|c|c|c|c|c|}
\hline $\begin{array}{l}\text { Definitions } \\
\text { (1) }\end{array}$ & $\begin{array}{l}\text { full time } \\
\text { men } \\
(2)\end{array}$ & $\begin{array}{l}\text { full time } \\
\text { women } \\
\text { (3) }\end{array}$ & $\begin{array}{l}\text { part time } \\
\text { women } \\
(4)\end{array}$ & $\begin{array}{l}\text { non working } \\
\text { women } \\
\text { (5) }\end{array}$ \\
\hline hourly wage main job & 31.16 & 25.85 & 25.43 & - \\
\hline log hourly wage main job & 3.34 & 3.17 & 3.11 & - \\
\hline hourly wage all jobs & 31.14 & 25.75 & 25.28 & - \\
\hline log hourly wage all jobs & 3.33 & 3.17 & 3.11 & - \\
\hline work experience & 20.23 & 18.10 & 17.28 & 12.69 \\
\hline age & 38.89 & 39.24 & 40.44 & 40.85 \\
\hline degree & 0.23 & 0.28 & 0.19 & 0.23 \\
\hline diploma & 0.08 & 0.13 & 0.11 & 0.09 \\
\hline certificate & 0.36 & 0.18 & 0.25 & 0.21 \\
\hline year 12 & 0.14 & 0.17 & 0.17 & 0.15 \\
\hline year 11 and below & 0.19 & 0.24 & 0.27 & 0.31 \\
\hline native & 0.82 & 0.76 & 0.82 & 0.81 \\
\hline eng speak immigrant & 0.09 & 0.10 & 0.09 & 0.07 \\
\hline non eng speak immigrant & 0.09 & 0.14 & 0.09 & 0.13 \\
\hline married & 0.77 & 0.69 & 0.82 & 0.76 \\
\hline log Household income net own earnings & 10.25 & 10.52 & 10.96 & 10.90 \\
\hline $\begin{array}{l}\text { disagrees preschool child suffers if mother } \\
\text { works full time }\end{array}$ & 0.43 & 0.54 & 0.47 & 0.36 \\
\hline youngest child aged 0-5 & 0.24 & 0.09 & 0.32 & 0.39 \\
\hline youngest child aged 6-11 & 0.14 & 0.12 & 0.23 & 0.14 \\
\hline youngest child aged 12-15 & 0.07 & 0.10 & 0.12 & 0.09 \\
\hline dependent child aged $<16$ & 0.45 & 0.31 & 0.67 & 0.62 \\
\hline \multicolumn{5}{|l|}{ Region } \\
\hline NSW & 0.30 & 0.27 & 0.29 & 0.30 \\
\hline Vic & 0.25 & 0.24 & 0.28 & 0.21 \\
\hline QLD & 0.23 & 0.28 & 0.23 & 0.26 \\
\hline SA & 0.08 & 0.08 & 0.09 & 0.08 \\
\hline WA & 0.09 & 0.07 & 0.08 & 0.09 \\
\hline Tas & 0.03 & 0.03 & 0.02 & 0.04 \\
\hline NT & 0.01 & 0.01 & 0.00 & 0.00 \\
\hline ACT & 0.01 & 0.01 & 0.02 & 0.01 \\
\hline supervisory duties & 0.60 & 0.54 & 0.39 & - \\
\hline \multicolumn{5}{|l|}{ size of firm workforce } \\
\hline less than 20 & 0.37 & 0.33 & 0.57 & - \\
\hline 20-199 & 0.41 & 0.44 & 0.32 & - \\
\hline 200 or over & 0.22 & 0.23 & 0.11 & - \\
\hline \multicolumn{5}{|l|}{ Occupation } \\
\hline managers & 0.19 & 0.15 & 0.04 & - \\
\hline professional & 0.18 & 0.21 & 0.12 & - \\
\hline technicians and trades & 0.24 & 0.06 & 0.06 & - \\
\hline $\begin{array}{l}\text { community and personal } \\
\text { services }\end{array}$ & 0.02 & 0.07 & 0.11 & - \\
\hline clerical and administrative & 0.07 & 0.30 & 0.33 & - \\
\hline sales workers & 0.07 & 0.11 & 0.21 & - \\
\hline machinery operators and drivers & 0.15 & 0.02 & 0.01 & - \\
\hline labourer & 0.08 & 0.08 & 0.12 & - \\
\hline number of observations & 1414 & 477 & 421 & 584 \\
\hline
\end{tabular}

Source: HILDA, wave 9, 2009. 
Figure1. Kernel density earnings estimates for full-time men and women

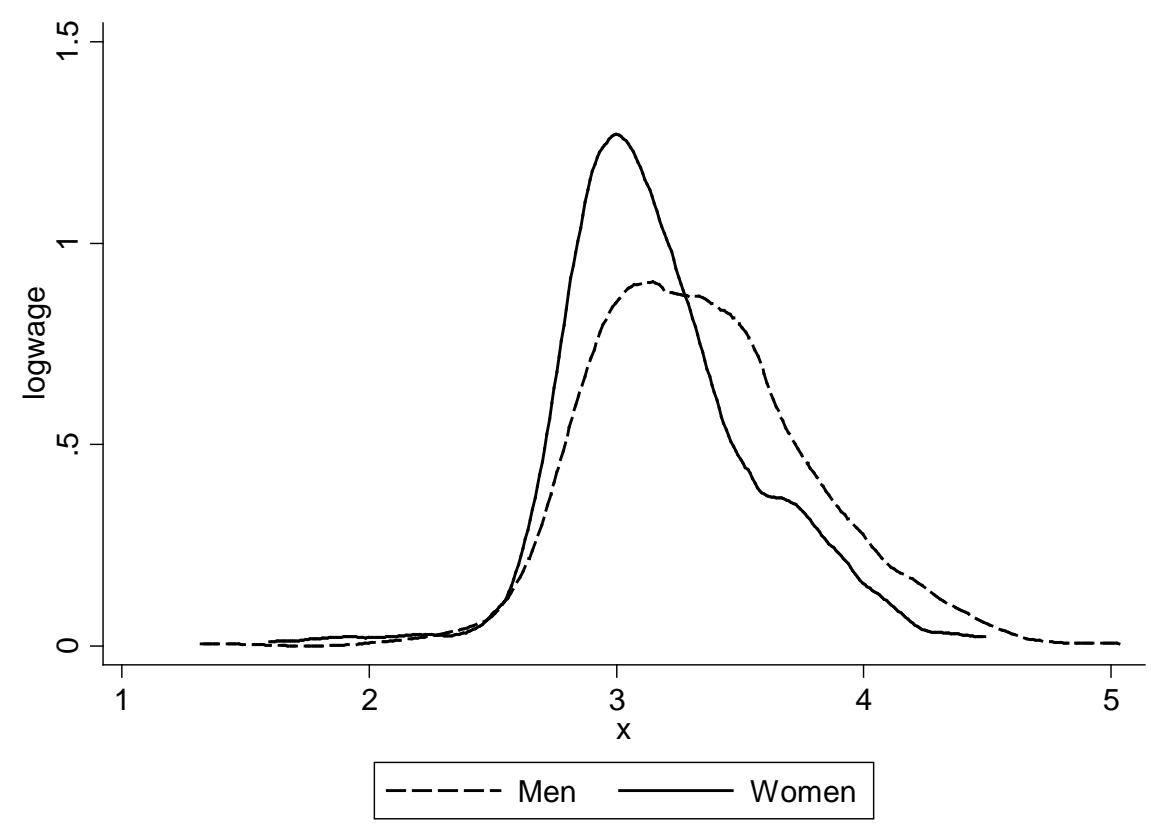

Figure 2. Unadjusted gender log wage gap, full-time employees in the private sector.

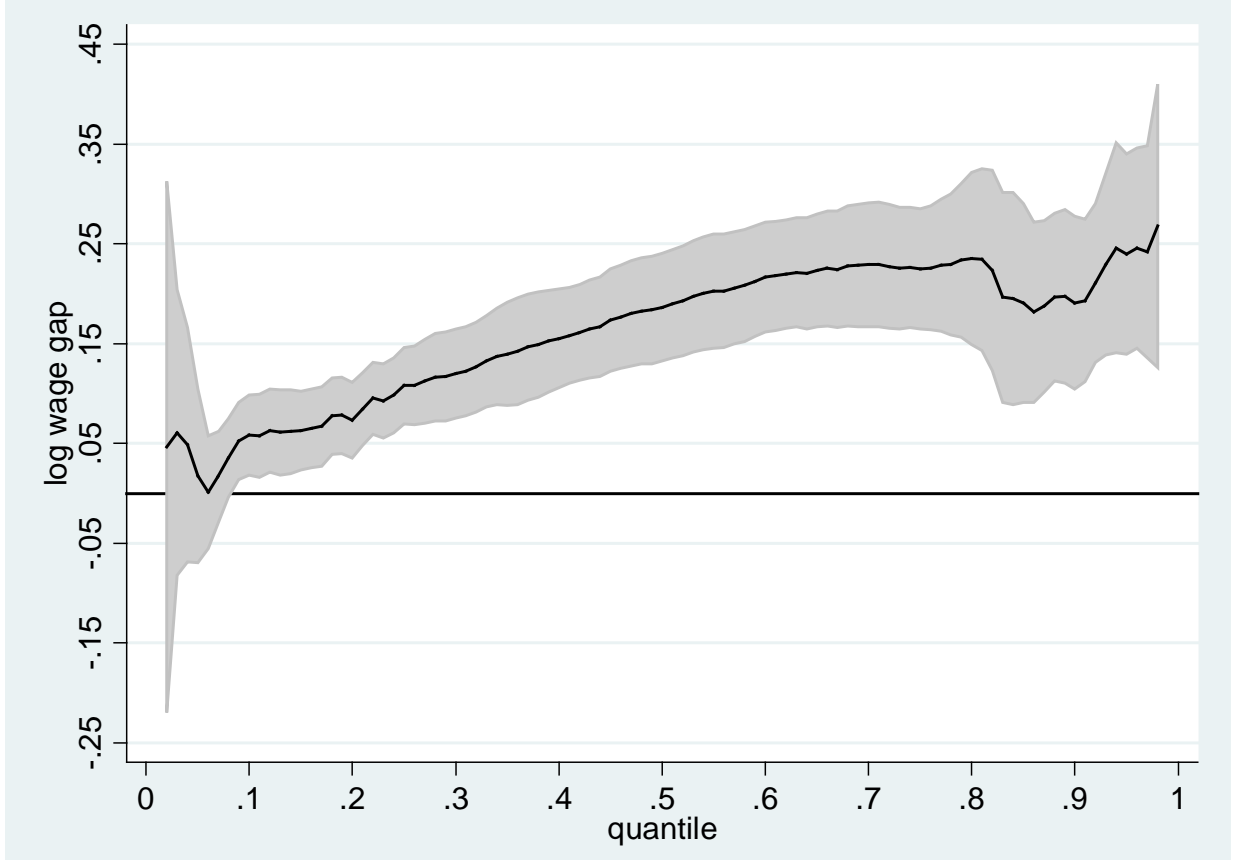


Table 2. Estimates of the incidence of full time work amongst women

\begin{tabular}{|c|c|c|c|c|}
\hline & \multicolumn{2}{|c|}{ Probit (1) } & \multicolumn{2}{|c|}{ Single Index (2) } \\
\hline & $\mathrm{B}$ & Std. Err. & $\mathrm{B}$ & Std. Err. \\
\hline work experience & $0.106^{*}$ & 0.02 & 0.106 & \\
\hline work experience squared & $-0.001^{*}$ & 0.0004 & $-0.001^{*}$ & 0.0002 \\
\hline \multicolumn{5}{|l|}{ highest level of education (ref: university) } \\
\hline Diploma & 0.060 & 0.13 & 0.050 & 0.05 \\
\hline Certificate & $-0.273^{*}$ & 0.11 & $-0.183^{*}$ & 0.05 \\
\hline Year 12 & -0.010 & 0.12 & -0.040 & 0.05 \\
\hline Year 11 or below & -0.132 & 0.11 & -0.076 & 0.05 \\
\hline age & $-0.091^{*}$ & 0.01 & -0.048 & 0.00 \\
\hline married & -0.141 & 0.09 & $-0.087^{\star}$ & 0.04 \\
\hline \multicolumn{5}{|l|}{ Migrant status (ref: native) } \\
\hline eng speak immigrant & 0.164 & 0.13 & 0.058 & 0.05 \\
\hline $\begin{array}{l}\text { non eng speak immigrant } \\
\text { disagrees that preschool child suffers }\end{array}$ & $0.312^{*}$ & 0.11 & $0.160^{*}$ & 0.05 \\
\hline if mother works full time & $0.231^{*}$ & 0.08 & $0.118^{*}$ & 0.04 \\
\hline youngest child aged 0-5 & $-1.420 *$ & 0.11 & $-0.783^{*}$ & 0.08 \\
\hline youngest child aged 6-11 & $-0.652^{\star}$ & 0.10 & $-0.613^{*}$ & 0.07 \\
\hline log household income net own earnings & $-0.151^{*}$ & 0.03 & $-0.079 *$ & 0.01 \\
\hline constant & $3.692^{*}$ & 0.44 & 3.692 & \\
\hline number of observations & 1735 & & 1735 & \\
\hline
\end{tabular}

Source: HILDA, Wave 9, 2009. * represents significance at $\mathrm{p}<0.05$. The constant and work experience coefficients in the single index model are normalised. Controls are included for region.

Figure 3. Sample selection

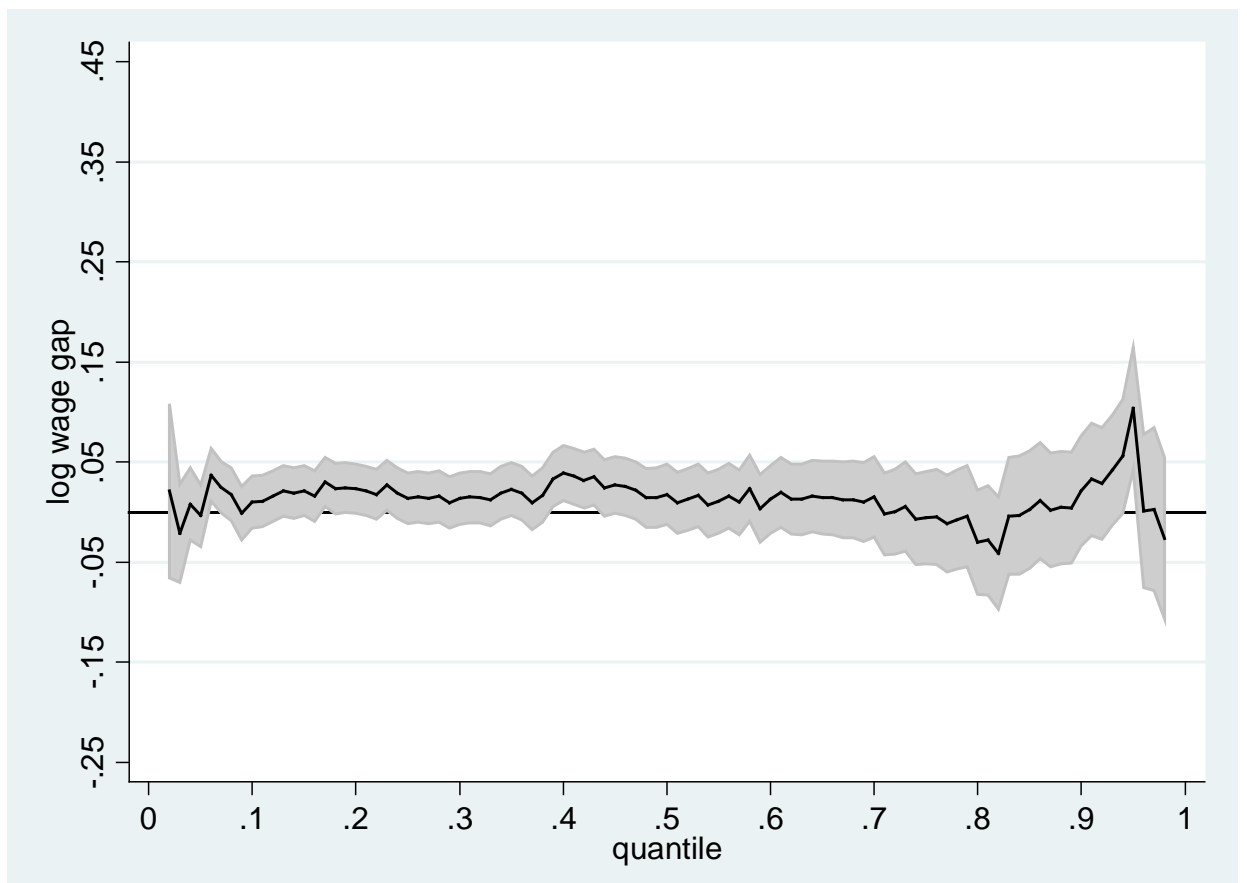


Figure 3a. Selection on observables

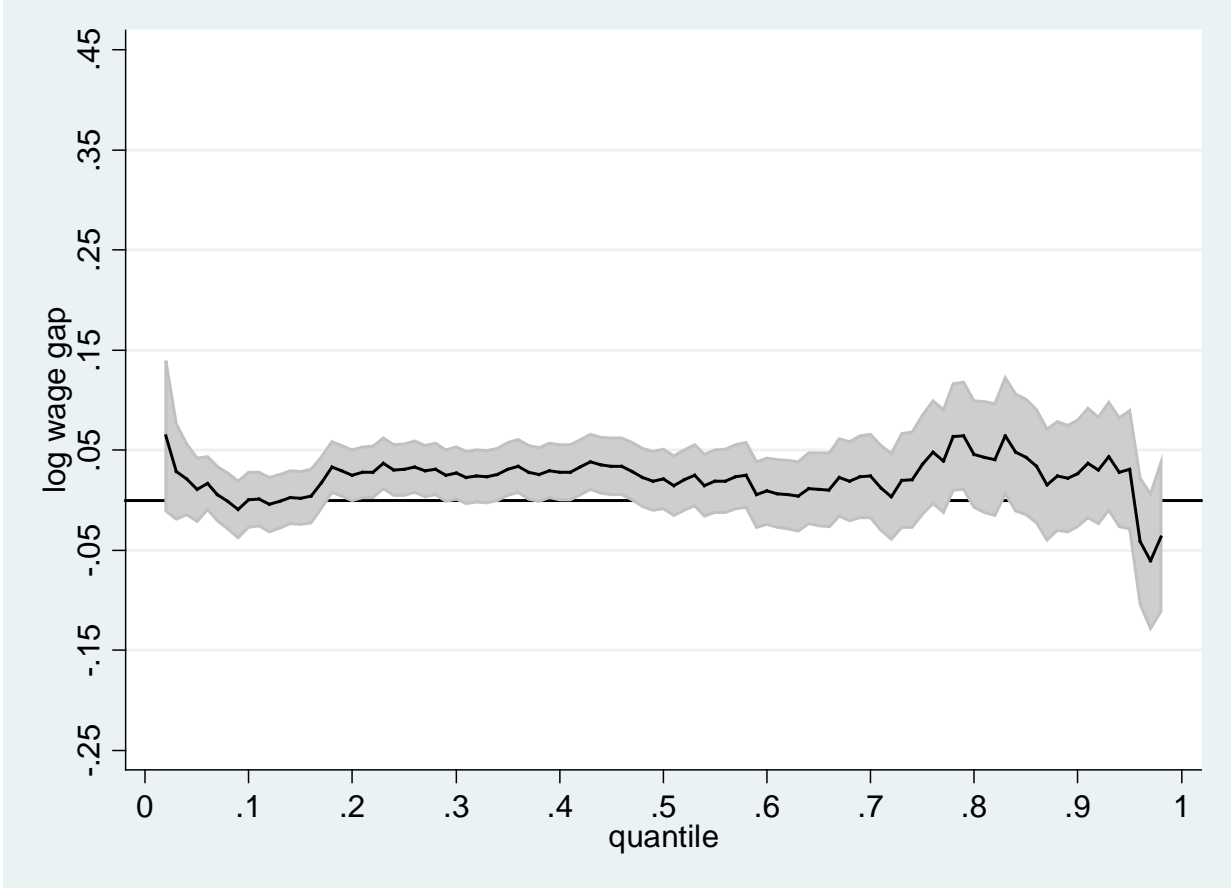

Figure 3b. Selection on unobservables

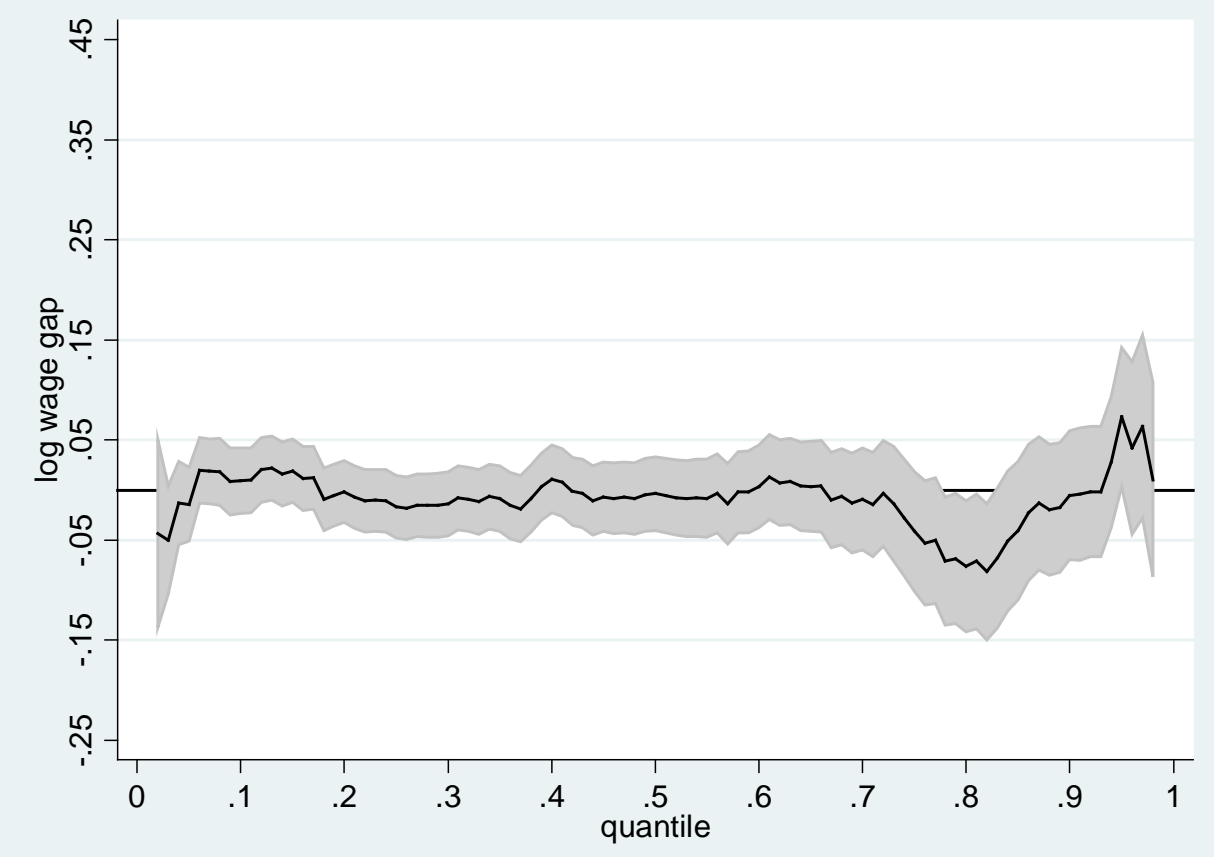


Table 3. Estimated earnings at example percentiles.

\begin{tabular}{|c|c|c|c|c|c|c|}
\hline \multicolumn{4}{|c|}{ Men } & \multicolumn{3}{|l|}{ Women } \\
\hline percentile & 20 & 50 & 80 & 20 & 50 & 80 \\
\hline \multicolumn{7}{|l|}{$\begin{array}{l}\text { highest level of education } \\
\text { (ref: university) }\end{array}$} \\
\hline Diploma & $-0.190^{\star}$ & $-0.215^{\star}$ & $-0.266^{\star}$ & -0.156 & $-0.196^{\star}$ & -0.050 \\
\hline Certificate & $-0.282^{\star}$ & $-0.289 *$ & $-0.347^{\star}$ & -0.158 & $-0.230^{*}$ & $-0.215^{\star}$ \\
\hline Year 12 & $-0.201^{*}$ & $-0.252^{\star}$ & $-0.289 *$ & -0.069 & $-0.252^{\star}$ & $-0.180^{\star}$ \\
\hline Year 11 or below & $-0.327^{\star}$ & $-0.316^{\star}$ & $-0.409 *$ & -0.149 & $-0.269 *$ & -0.110 \\
\hline work experience & $0.032^{*}$ & $0.031^{*}$ & $0.037^{*}$ & 0.015 & 0.016 & 0.015 \\
\hline work experience squared & $-0.001^{*}$ & $-0.001^{*}$ & $-0.001^{*}$ & -0.0003 & -0.0003 & -0.0002 \\
\hline married & 0.095 * & $0.101^{*}$ & 0.062 & -0.011 & -0.002 & -0.014 \\
\hline \multicolumn{7}{|l|}{ Migrant status (ref: native) } \\
\hline eng speak immigrant & -0.027 & 0.022 & 0.040 & -0.022 & -0.001 & 0.016 \\
\hline non eng speak immigrant & $-0.106^{*}$ & $-0.121^{*}$ & -0.123 & 0.070 & -0.034 & 0.062 \\
\hline supervisory duties & $0.057^{*}$ & $0.092^{*}$ & $0.089^{*}$ & 0.054 & $0.070^{*}$ & $0.126^{*}$ \\
\hline \multicolumn{7}{|l|}{ Size of firm (ref: workforce<20) } \\
\hline workforce 20-199 & $0.115^{\star}$ & $0.102^{\star}$ & $0.117^{*}$ & 0.072 & 0.033 & 0.002 \\
\hline workforce >200 & $0.324^{*}$ & $0.308^{*}$ & $0.347^{*}$ & $0.195^{*}$ & $0.219 *$ & $0.194^{*}$ \\
\hline \multicolumn{7}{|l|}{ Occupation (ref: labourer) } \\
\hline managers & $0.183^{\star}$ & $0.235^{\star}$ & $0.342^{\star}$ & $0.345^{\star}$ & $0.314^{*}$ & $0.592^{\star}$ \\
\hline professional & $0.235^{*}$ & $0.291^{*}$ & $0.297^{*}$ & $0.368^{*}$ & $0.350^{*}$ & $0.440^{*}$ \\
\hline technicians and trades & $0.169^{*}$ & $0.210^{*}$ & $0.211^{*}$ & 0.157 & 0.127 & 0.282 \\
\hline $\begin{array}{l}\text { community and personal } \\
\text { services }\end{array}$ & 0.029 & 0.073 & 0.028 & 0.078 & -0.026 & 0.012 \\
\hline clerical and administrative & 0.092 & $0.108^{*}$ & 0.132 & 0.208 & $0.143^{*}$ & $0.153^{*}$ \\
\hline sales workers & 0.035 & -0.016 & 0.051 & 0.093 & 0.036 & 0.068 \\
\hline $\begin{array}{l}\text { machinery operators and } \\
\text { drivers }\end{array}$ & 0.050 & 0.056 & 0.068 & 0.084 & 0.088 & 0.559 \\
\hline constant & $2.575^{\star}$ & $2.796^{\star}$ & $3.065^{\star}$ & $2.540^{*}$ & $2.880^{*}$ & $2.946^{*}$ \\
\hline Pseudo R-squared & 0.20 & 0.24 & 0.26 & 0.15 & 0.23 & 0.31 \\
\hline Number observations & 1414 & 1414 & 1414 & 477 & 477 & 477 \\
\hline
\end{tabular}

Source: HILDA, Wave 9, 2009. * represents significance at $\mathrm{p}<0.05$. The constant and work experience coefficients in the single index model are normalised. Controls are included for region. 
Figure 4. Log wage gap between full-time men's wages and the wages that full-time women would earn if they had men's distribution of characteristics and women's returns to these characteristics

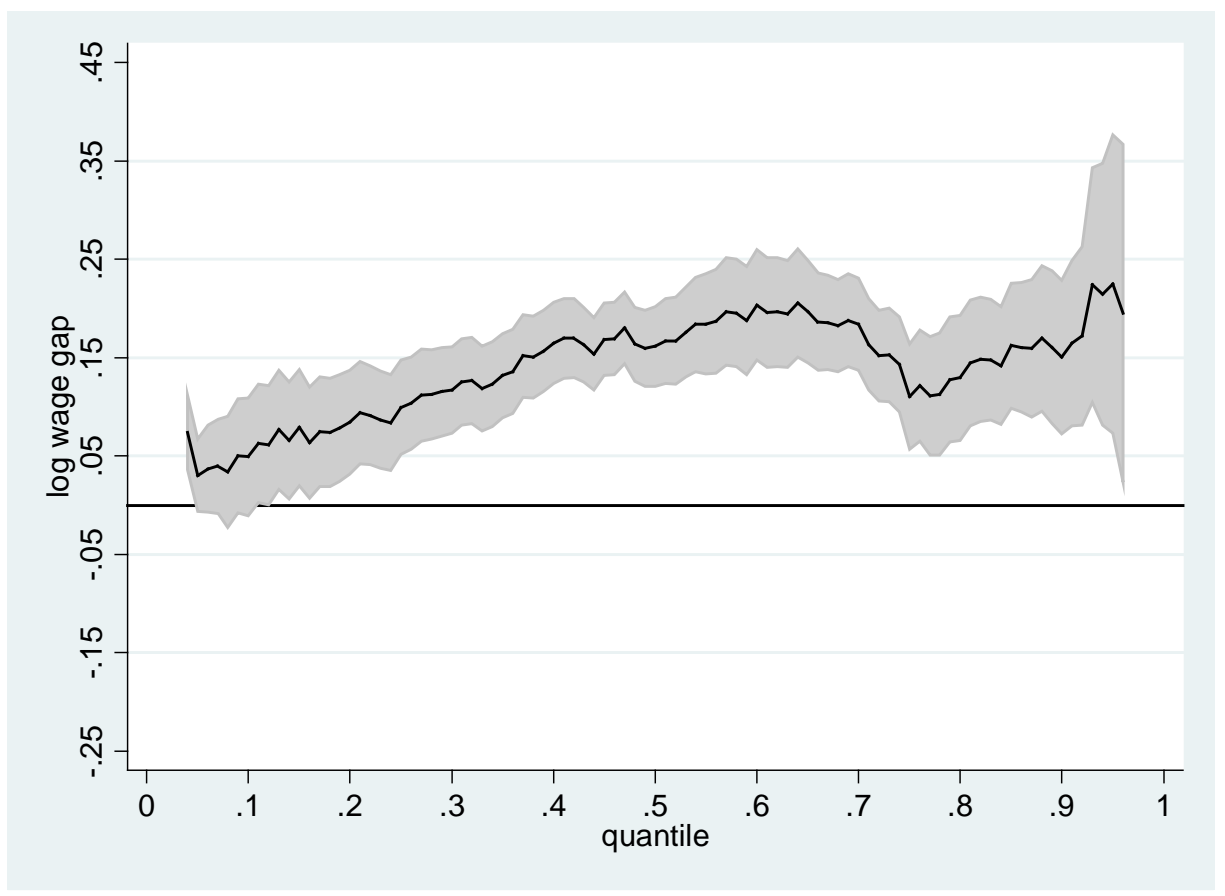

Figure 5. Log wage gap between full-time men and full-time women paid like men

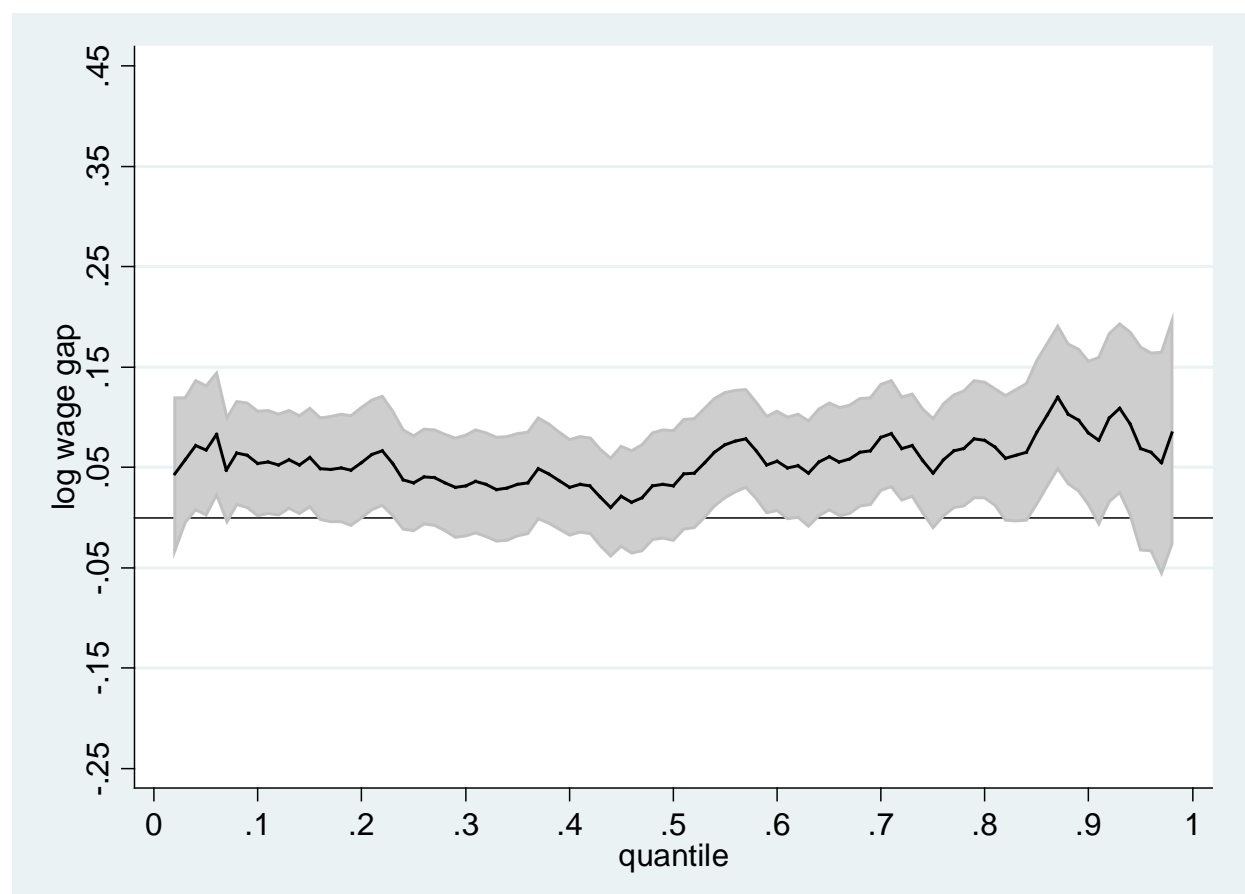

Controls included for education, experience, marital status, region, supervisory duties, size of the workplace and occupation. 
Appendix. Table A1. Descriptive statistics.

\begin{tabular}{|c|c|c|c|c|c|c|c|c|c|c|c|c|c|c|c|c|}
\hline \multirow[b]{3}{*}{ Average aross hourly wage } & \multicolumn{4}{|c|}{ female full time } & \multicolumn{4}{|c|}{ male full time } & \multicolumn{4}{|c|}{ female part time } & \multicolumn{4}{|c|}{ female non working } \\
\hline & mean & s. dev & $\min$ & $\max$ & mean & s. dev & $\min$ & $\max$ & mean & s.dev & $\min$ & $\max$ & mean & s. dev & $\min$ & Max \\
\hline & 25.75 & 11.65 & 4.9 & 88.9 & 31.14 & 15.87 & 1.5 & 141.5 & 25.28 & 17.61 & 2.0 & 200.0 & & & & \\
\hline log average gross hourly wage & 3.17 & 0.40 & 1.6 & 4.5 & 3.33 & 0.45 & 0.4 & 5.0 & 3.11 & 0.46 & 0.7 & 5.3 & & & & \\
\hline \multicolumn{17}{|l|}{ education } \\
\hline degree & 0.28 & 0.45 & 0.0 & 1.0 & 0.23 & 0.42 & 0.0 & 1.0 & 0.19 & 0.40 & 0.0 & 1.0 & 0.23 & 0.42 & 0.0 & 1.0 \\
\hline diploma & 0.13 & 0.34 & 0.0 & 1.0 & 0.08 & 0.27 & 0.0 & 1.0 & 0.11 & 0.31 & 0.0 & 1.0 & 0.09 & 0.29 & 0.0 & 1.0 \\
\hline certificate & 0.18 & 0.39 & 0.0 & 1.0 & 0.36 & 0.48 & 0.0 & 1.0 & 0.25 & 0.43 & 0.0 & 1.0 & 0.21 & 0.41 & 0.0 & 1.0 \\
\hline year 12 & 0.17 & 0.37 & 0.0 & 1.0 & 0.14 & 0.34 & 0.0 & 1.0 & 0.17 & 0.38 & 0.0 & 1.0 & 0.15 & 0.36 & 0.0 & 1.0 \\
\hline year 11 and below & 0.24 & 0.42 & 0.0 & 1.0 & 0.19 & 0.39 & 0.0 & 1.0 & 0.27 & 0.44 & 0.0 & 1.0 & 0.31 & 0.46 & 0.0 & 1.0 \\
\hline native & 0.76 & 0.42 & 0.0 & 1.0 & 0.82 & 0.39 & 0.0 & 1.0 & 0.82 & 0.39 & 0.0 & 1.0 & 0.81 & 0.40 & 0.0 & 1.0 \\
\hline eng speak immigrant & 0.10 & 0.29 & 0.0 & 1.0 & 0.09 & 0.29 & 0.0 & 1.0 & 0.09 & 0.28 & 0.0 & 1.0 & 0.07 & 0.25 & 0.0 & 1.0 \\
\hline non eng speak immigrant & 0.14 & 0.35 & 0.0 & 1.0 & 0.09 & 0.29 & 0.0 & 1.0 & 0.09 & 0.29 & 0.0 & 1.0 & 0.13 & 0.33 & 0.0 & 1.0 \\
\hline married & 0.69 & 0.46 & 0.0 & 1.0 & 0.77 & 0.42 & 0.0 & 1.0 & 0.82 & 0.39 & 0.0 & 1.0 & 0.76 & 0.43 & 0.0 & 1.0 \\
\hline age & 39.24 & 9.04 & 25.0 & 55.0 & 38.89 & 8.63 & 25.0 & 55.0 & 40.44 & 8.15 & 25.0 & 55.0 & 40.85 & 8.94 & 25.0 & 55.0 \\
\hline log Household income net own earnings & 10.52 & 1.49 & 4.0 & 13.7 & 10.25 & 1.32 & 3.6 & 12.9 & 10.96 & 0.93 & 4.2 & 13.0 & 10.90 & 1.02 & 3.0 & 13.7 \\
\hline disagree that preschool child suffers if mother works full time & 0.54 & 0.50 & 0.0 & 1.0 & 0.43 & 0.49 & 0.0 & 1.0 & 0.47 & 0.50 & 0.0 & 1.0 & 0.36 & 0.48 & 0.0 & 1.0 \\
\hline youngest child aged 0-5 & 0.09 & 0.29 & 0.0 & 1.0 & 0.24 & 0.43 & 0.0 & 1.0 & 0.32 & 0.47 & 0.0 & 1.0 & 0.39 & 0.49 & 0.0 & 1.0 \\
\hline youngest child aged 6-11 & 0.12 & 0.32 & 0.0 & 1.0 & 0.14 & 0.34 & 0.0 & 1.0 & 0.23 & 0.42 & 0.0 & 1.0 & 0.14 & 0.34 & 0.0 & 1.0 \\
\hline youngest child aged 12-15 & 0.10 & 0.30 & 0.0 & 1.0 & 0.07 & 0.25 & 0.0 & 1.0 & 0.12 & 0.33 & 0.0 & 1.0 & 0.09 & 0.29 & 0.0 & 1.0 \\
\hline dependent child aged <16 & 0.31 & 0.46 & 0.0 & 1.0 & 0.45 & 0.50 & 0.0 & 1.0 & 0.67 & 0.47 & 0.0 & 1.0 & 0.62 & 0.49 & 0.0 & 1.0 \\
\hline supervisory duties & 0.54 & 0.50 & 0.0 & 1.0 & 0.60 & 0.49 & 0.0 & 1.0 & 0.39 & 0.49 & 0.0 & 1.0 & & & & \\
\hline size of firm workforce <20 & 0.33 & 0.47 & 0.0 & 1.0 & 0.37 & 0.48 & 0.0 & 1.0 & 0.57 & 0.50 & 0.0 & 1.0 & & & & \\
\hline size of firm workforce 20-199 & 0.44 & 0.50 & 0.0 & 1.0 & 0.41 & 0.49 & 0.0 & 1.0 & 0.32 & 0.47 & 0.0 & 1.0 & & & & \\
\hline size of firm workforce >200 & 0.23 & 0.42 & 0.0 & 1.0 & 0.22 & 0.41 & 0.0 & 1.0 & 0.11 & 0.31 & 0.0 & 1.0 & & & & \\
\hline \multicolumn{17}{|l|}{ Occupation } \\
\hline managers & 0.15 & 0.36 & 0.0 & 1.0 & 0.19 & 0.39 & 0.0 & 1.0 & 0.04 & 0.20 & 0.0 & 1.0 & & & & \\
\hline professional & 0.21 & 0.41 & 0.0 & 1.0 & 0.18 & 0.38 & 0.0 & 1.0 & 0.12 & 0.33 & 0.0 & 1.0 & & & & \\
\hline technicians and trades & 0.06 & 0.25 & 0.0 & 1.0 & 0.24 & 0.43 & 0.0 & 1.0 & 0.06 & 0.24 & 0.0 & 1.0 & & & & \\
\hline community and personal services & 0.07 & 0.26 & 0.0 & 1.0 & 0.02 & 0.15 & 0.0 & 1.0 & 0.11 & 0.32 & 0.0 & 1.0 & & & & \\
\hline clerical and administrative & 0.30 & 0.46 & 0.0 & 1.0 & 0.07 & 0.25 & 0.0 & 1.0 & 0.33 & 0.47 & 0.0 & 1.0 & & & & \\
\hline sales workers & 0.11 & 0.31 & 0.0 & 1.0 & 0.07 & 0.25 & 0.0 & 1.0 & 0.21 & 0.41 & 0.0 & 1.0 & & & & \\
\hline machinery operators and drivers & 0.02 & 0.14 & 0.0 & 1.0 & 0.15 & 0.35 & 0.0 & 1.0 & 0.01 & 0.11 & 0.0 & 1.0 & & & & \\
\hline labourer & 0.08 & 0.27 & 0.0 & 1.0 & 0.08 & 0.28 & 0.0 & 1.0 & 0.12 & 0.32 & 0.0 & 1.0 & & & & \\
\hline \multicolumn{17}{|l|}{ Region } \\
\hline NSW & 0.27 & 0.44 & 0.0 & 1.0 & 0.30 & 0.46 & 0.0 & 1.0 & 0.29 & 0.45 & 0.0 & 1.0 & 0.30 & 0.46 & 0.0 & 1.0 \\
\hline Vic & 0.24 & 0.43 & 0.0 & 1.0 & 0.25 & 0.44 & 0.0 & 1.0 & 0.28 & 0.45 & 0.0 & 1.0 & 0.21 & 0.41 & 0.0 & 1.0 \\
\hline QLD & 0.28 & 0.45 & 0.0 & 1.0 & 0.23 & 0.42 & 0.0 & 1.0 & 0.23 & 0.42 & 0.0 & 1.0 & 0.26 & 0.44 & 0.0 & 1.0 \\
\hline SA & 0.08 & 0.28 & 0.0 & 1.0 & 0.08 & 0.27 & 0.0 & 1.0 & 0.09 & 0.28 & 0.0 & 1.0 & 0.08 & 0.28 & 0.0 & 1.0 \\
\hline WA & 0.07 & 0.26 & 0.0 & 1.0 & 0.09 & 0.29 & 0.0 & 1.0 & 0.08 & 0.27 & 0.0 & 1.0 & 0.09 & 0.28 & 0.0 & 1.0 \\
\hline Tas & 0.03 & 0.18 & 0.0 & 1.0 & 0.03 & 0.16 & 0.0 & 1.0 & 0.02 & 0.13 & 0.0 & 1.0 & 0.04 & 0.19 & 0.0 & 1.0 \\
\hline NT & 0.01 & 0.11 & 0.0 & 1.0 & 0.01 & 0.10 & 0.0 & 1.0 & 0.00 & 0.05 & 0.0 & 1.0 & 0.00 & 0.06 & 0.0 & 1.0 \\
\hline ACT & 0.01 & 0.09 & 0.0 & 1.0 & 0.01 & 0.12 & 0.0 & 1.0 & 0.02 & 0.14 & 0.0 & 1.0 & 0.01 & 0.12 & 0.0 & 1.0 \\
\hline Number of observations & 477 & & & & 1414 & & & & 421 & & & & & 584 & & \\
\hline
\end{tabular}

Source: HILDA Wave 9, 2009. 